philosophy of difference, provides for fundamentally new forms and methods of understanding discourse, narrative, and literary text. The main feature of hermeneutics of difference is the traductive interpretation of the relation of elements in the conditional semantic whole, which denies any hierarchy, continuity and sequence, and relies on total correlation as a mutual transition. Difference thus emerges as an epistemological instruction and a fundamental cognitive setting for understanding and experiencing decentralized fragmented reality. Barthelme.

Key words: subject, hermeneutics of difference, probabilistic subject, narrative, postmodern, text, D.

Одержано редакиією $\quad 22.10 .2019$

Прийнято до публікаиії 04.12.2019

УДК 338:23

DOI: $10.31651 / 2076-5894-2019-2-14-23$
PECHERANSKYI Igor Petrovych,

Doctor of Philosophical Sciences, Associate Professor at the Department of Philosophy

Kiev National University of Culture and Arts, e-mail: ipecheranskiy@ukr.net

\title{
THE PRINCIPLE OF NON-INTERFERENCE OF POWER AND ITS ETHICAL JUSTIFICATION IN THE WORK OF HANS-HERMANN HOPPE
}

In the article the contents aspects and methodological meaning of non-interference of power are opened and its ethical justification in the works of the famous representative of "a new Austrian school» Hans-Hermann Hoppe is analyzed. Methodological basis of the research is the use of both general scientific and sociological methods. The theoretical and methodological basis of work is the system of general scientific and special methods, namely: historical-logical method, theoretical generalization and systematization. It defends the universalism of private property ethics, which transforms into the creation of a speculative concept of "natural order» implemented within the bounds of anarcho-capitalism MisesRothbard direction of «a new Austrian school». It is proved that the scientist, building on his a priori, praxeology, and the principles of self-belonging and homestead, creates his own theory of the economy of power, where the main object of criticism is the state as an institutionalized form of coercion and exploitation. For him power - is a coercion which becomes horribly devastating, turning into a state institution. It kills the creative potential of a person by reducing or even completely destroying the level of "domination over nature», and also threatening the normal work of the market, while having the "right» of legitimate violence, receives a clear preference. That is why the scientist places great emphasis on the ethical substantiation of the principle of non-interference of government in economic processes.

Key words: "a new Austrian school», Hans-Hermann Hoppe, apriorizm, praxeology, universalism, private property ethics, non-interference of power.

Formulation of the problem. The topicality of this research work is due to the need to find new methods for analyzing economic reality, within which the category of «power» occupies one of the central places. Taking into account the modification of socio-economic processes caused by the controversial combination of unipolar dominant US and the increase of unpredictable multipolarity in the economic process, increasing the role of progressive countries in the international economy, growing food and water shortages, increasing the number of armed conflicts, transferring terrorist activity in cyberspace, low effectiveness of the crisis politics in countries that make up the core of the global financial system, the issue of the ratio is economic and political power, as well as the boundaries of state regulation and market opportunities, become critical and require critical and comprehensive analysis in the theoretical key.

In this sense, there is a need to explore methodological approaches and theories based on them that reveal the specifics of economic power, which is very closely linked to political processes. For this is necessary to pay attention on the heritage of «a new Austiran school» (the 
term which firstly appears in the work by O. Shuliak and G. Unterköfler «Austrian school of economic theory: history of ideas, representatives and establishments» and describes the theoretical and methodological direction of economic science, presented by followers of the ideas of the Austrian school from the 1970's to the present).

It is important to underline that the Austrian school is a unique phenomenon in the history of the economical thoughts. It was founded in 1871 it is still existing and has six generations, work of which reach out more than 140 years history. Its genealogy is the following: 1) the first generation or founders (Carl Menger); 2) the second generation or development (Eugen von Bohm-Bawerk, Friedrich von Wieser, E. Sax, R. Zuckerkandl, V. Mataja, R. Schüller and others); 3) the third generation (Ludwig von Mises, Richard von Strigl, E. Shams, L. Illi); 4) the fourth generation or «dissolution in the main stream of economic theory» (Friedrich von Hayek, F. Machlup, O. Morgenstern, F. Kaufmann, A. Schütz and others); 5) the fifth generation or «Austrian renaissance» (M. Rothbard, I. Kirzner, L. Lachmann); 6) the sixth generation or «a new Austrian school» (H.-H. Hoppe, J. Huhlsmann, V. Blok, K. Keun, J.-H de Soto, R. Ebeling, P. Leeson, T. Woods, L. White, and others) [1].

In spite of the long history of its existence, the Austrians managed to preserve the theoretical and methodological core developed by the first generations of the school, provided that it is substantially complemented. Nowadays, the new school is basically represented American researchers, the creation of whom is accepted to divide into two directions: Mises-Rothbard view and Hayekian view. The representatives of the first one have accepted the study of M. Rothbard who was a strong supporter of apriorizm by Ludwig von Mises, had developed the ethical and ideological basis of the theory of the Austrian school, picked up and developed by other supporters of the aforementioned direction. The others ones, followed by Friedrich von Hayek, departed from apriorizm and praxeology, taking methods (empirical and statistical, mathematical and graphic modeling) and a number of the mainstream theories (theory of rational choice, game theory, concept of market equilibrium, etc.), and also supplemented it with a dynamic approach and basic provisions developed representatives of previous generations of the school.

The similar studies are also relevant for the reason that today socio-economic sciences and their methodological bases require revision and rethinking: the crisis of research in social processes is becoming increasingly apparent in view of the reduced predictability of the concepts of scientists involved in this sector. Especially if we recall the global financial crisis of 2008-2009, when many theoreticians, based on their studies on Mainstream Economics methodology, were not able to offer effective solutions for solving macroeconomic problems. In this regard, there is a problem of finding theoretical and methodological alternative offered by an Austrian school, overcoming the limitations of the mainstream and instrumentalism approach and critically rethinking the provisions of the Keynesian theory.

In this way for the special attention from the heredity researchers of Austrian economic school deserves the creative works of Hans Hermann Hoppe (1949 year of birth). His main works are «A theory of socialism and capitalism: economics, politics, and ethics» (1989), «Marxist and Austrian Class Analysis» (1990), «Economic Science and the Austrian Method» (1995), «Murray N. Rothbard: Economics, Science, and Liberty» (1999), «Democracy - the god that failed: the economics \& politics of monarchy, democracy \& natural order» (2001), «The Economics and Ethics of Private Property» (2006) and others.

Analysis of recent researches and publications. In the Ukrainian scientific literature «a new Austrian school» is almost not presented, as, in fact; the Austrian tradition in general is presented mainly at the level of individual articles and sections in the educational literature. Modern Austrians are given several paragraphs in review articles and textbooks, which mainly contains an analysis of a single general Austrian theoretical content. Among other national discourse should be highlighted the works by O. Zaostrovtseva, O. Kovaliova, P. Usanova. Special attention should be given to the article by M. Konstantinova «Analytical anarchism: the problem of determination and demarcation» (2012), where the author considers the economical content of works P. Böhttke and 
H.-H. Hoppe as the theorists of anarchism. The potent achievement is the thesis by G. Bazhenov «Relations between government and the market in the interpretation of the newest representatives of the Austrian school» (1970-2010's)». Among foreign sources should be given the special attention to the works by Jesús Huerta de Soto, P. Böhttke and P. Leeson, O. Shuliak and G. Unterköfler.

Purpose. The goal of the article is the analysis of the principle of non-interference of power in the context of ethical economic study of one of the most known representative of «a new Austrian school» Hans-Hermann Hoppe. This objective is attained against the background of the disclosure of the specificity of the universalism of the Mises-Rothbard view, associated with apriorizm, the rejection of the empirical method (anti-realism), and the propensity for the political ideology of libertarianism, which is also inherent in H.-H. Hoppe. Working on a set of methodological ideas, the representatives of this direction of the new Austrian school, by their ontological convictions, tended more to the Marxist paradigm, with the only difference that Marxism called and predicted the socialization of the means of production and the emergence of the socialist and, subsequently, communist socioeconomic formation, on the other hand, the Austrians, sharing an approach to the state, offered an anarcho-capitalist paradigm, emphasizing the exploitative nature of the capitalist mode of production and the standing tendency to maximize private-ownership capital.

Presenting the main research material. During the period from the beginning of $1870^{\text {th }}$ till the middle of $1930^{\text {th }}$ the Austrian school reached its development. In 1933 Ludwig von Mises stressed that along with the fact that it is accepted in the framework of economic theory to distinguish Anglo-American, Austrian and Lausanne schools, in fact, «these three schools of economic thought differ only in a way of expressing some fundamental ideas; their division is more closely connected with the terminology and specificity of presentation of concepts than the essence of their teachings» [2, p. 214]. In essay «Austrian school of the economic theory», Friedrich von Hayek pointed out that the greatest success of a school is the situation when it ceases to exist, because its main ideals become part of the dominant paradigm. The development of Austrian (sometimes it is called Viennese) school leads to the fusion of ideas that originate from C. Menger, from studying of W. Jevons (though Ph. Wicksteed), L. Walras (through V. Pareto) and especially, from ideas by A. Marshall [3, p. 67]. Thus both researchers decided that the Austrian school has not been the separate direction of the economic theory but rather it is a part of a general theory of the economic science. And this is confirmed by representatives of the fourth generation of the Austrian school, for example, the figures of P. Rosenstein-Rodan or O. Morgenstern, who are not associated with the Austrian paradigm.

It is important to emphasize that the Austrian school economists never acted within the same methodological system and were actively discussing different concepts, concepts and principles. In spite of this, F. Machlup in the article «Ludwig von Mises: A Scholar Who Would Not Compromise» (1981) tried to distinguish six main provisions, which, in his opinion, share all the pupils of the Austrian school. Among them are: 1) methodological individualism (the simplest centers of economic theory are the actions of individuals, carried out in accordance with private plans and spontaneously lead to the formation of economic order); 2) methodological subjectivity (economic theory perceives the ultimate goals and value judgments of individuals, considered in the light of their subjective perception, as a given); 3) tastes and preferences (demand for goods and services - the result of a subjective assessment of the individual's ability to meet the relevant goods and services); 4) alternative costs (all the actions of the individual are related to costs: any choice in favor of something leads to a loss of profit, since an individual could use available resources in an alternative way; therefore, alternative costs - the best alternative for alternative use of resources); 5) marginality (economic decisions depend on the value of the last unit: utility value, costs, income, resource productivity are determined by means of the limit values); 6) intertemporal structure of production and consumption (all decisions are made in time: the distribution of the individual resources for production and consumption in time is determined by the temporary benefits of individuals) [4].

Besides these six based principles, F. Machlup introduces two additional ones - consumer 
sovereignty and political individualism. At the same time, he observes that these additional principles are supported by the majority of Mises students, spread after the center of school moved from continental Europe to the United States, under the influence of the Libertarian program. It should also be noted that these principles are mainly distributed among researchers of the fifth and sixth generations of the Austrian school. As a representative of the fourth generation of Austrians, F. Machlup mainly perceived those concepts and ideas that were developed before the 1920's. And in the 1920's and 1930's, there were known «Socialist calculation debate», in which the Austrians emphasized the dynamic nature of the market process and the importance for the economy as a whole of the class of entrepreneurs operating in a radical uncertainty. Including this discussion, the economist of the fifth generation of the Austrian school I. Kirzner, agrees with the six main provisions of F. Machlup, adds two more [1, p. 449]: firstly, the markets are processes (the view of markets and competition as the processes of opening and learning), and secondly, a radical uncertainty that penetrates all our actions and is a total context.

The provisions allocated by F. Machlup and I. Kirzner unite the Austrians into a separate methodological program of economic theory, which was developed in the work of researchers of the fifth and sixth generations. Based on these methodological benchmarks, they build an analysis of the relationship between power and the market. Further deepening of differences and differences in the ranks of the Austrian school was due to the growing discrepancies between L. von Mises and F. von Hayek on the question of the method. The apriorizm and the works based on it, L. von Mises inherited in his work M. Rothbard, taking a course on the construction of the theory of human activity on its absolute scale, which resulted in the creation of a science-like ethical doctrine of libertarianism and influenced the development of the theory of relations between power and economic processes.

Among the Austrians of the sixth generation the most important scientist of Mises-Rothbard direction is considered to be the Hans-Hermann Hoppe. Together with other followers of Mises and Rothbard, he takes as the basic and basic method applied to research within the social sciences, only praxeology (apriorizm), and also inclined to conservative views on the political, legal, and sociocultural values that contribute to marginalization this direction of the school within the ideological spectrum of economic science. As a student of Rothbard, H.-H. Hoppe supports the teacher's apriorizm and also discovers Hayek that he «is based on the intellectual tradition of British empiricism and skepticism, being an obvious opponent of continental rationalism, supported by Menger, Böhn-Bawerk, Mises and Rothbard» [5, p. 223].

For H.-H. Hoppe, as well as for the majority of the Mises-Rothbard direction of the new Austrian school, apriorizm and praxeology of theoretical discipline, which serves as the basis for economic theory, develops to the level of the basis of human knowledge as such. The apriorizm is completely subordinated to epistemology, which ultimately leads the Austrians in this direction to the methodological setting, according to which, if based on praxeology and its axioms; it is possible to «open» the laws of ethics and to carry out a final justification of certain ethical principles. The basis of theoretical constructions H.-H. Hoppe is the ethical theory of libertarianism, which the Austrian, applying praxeology, seeks to logically and rationally justify. For the ethics of libertarianism, the principle of belonging is the key, according to which the individual and only he owns the property of his body, as well as the principle of homestead principle, which states that the ownership of a natural resource that no one previously owned has only the one who first finds it, will use, transform, etc.

In the article «On the Ultimate Justification of the Ethics of Private Property» (1988) H.-H. Hoppe, relying on the concept of argument apriorizm, argues as follows: the question of justice arises only in a dispute in which the parties can make assumptions. An individual is able to argue, that is, to bring evidence and arguments in favor of their judgments, refute or agree with the assumptions of the interlocutor. According to Hoppe, this is possible only if the parties to the dispute have the right to own themselves. A lengthy dispute is possible only if there is not only the right to own body, but also the ability (right) to assign rare resources that the participant discovers 
and uses the first, that is, before they are discovered and used by another. If the individual, who considers a resource as his property, could approach other people and claim the right to use this resource, since, in their opinion, it is in common ownership, then nobody would be able to dispose of this resource, because it would have been You must obtain permission from all past, present and future owners.

According to the concept of H.-H. Hoppe, given that individuals as parties to the dispute are alive and can make assumptions, the ethics of property rights are capable, rational and logically verified, unlike other ethical systems. That is, the rights of individuals to their own bodies, as well as the rare, determined according to the principle of homestead resources, existing in the original, and not assigned to anyone later, result in a result: the free discussion of the issue of justice between two and more parties to the dispute, and, therefore, it becomes possible economic free exchange and there is a market order.

The Austrian, appealing to the tradition of natural law, deduces the notion of natural order, which is an obvious curvy in the direction of classical political economy. In his works, relying on the above principles, he shares two ways of obtaining and increasing wealth, noting that both the first and the second are natural for man. You can either grow rich either through the development of new resources, the production and sale of goods and services, the accumulation of savings or the conclusion of commercially viable deals, or through the expropriation of those who go the first way. In any society, there are those who choose both the first and the second way.

The difference between the natural order and other configurations of society lies in the absence or presence of a monopolist compelled to compel, without asking for consent, to pay taxes to all who live in the territory under his control. The very natural order of H.-H. Hoppe defines as «a social system free of monopoly [violence and coercion] and taxation» [6, p. xxi]. Including the natural environment, any of the limited resources, including all land, is privately owned, each enterprise is based on voluntarily beneficial buyers or private sponsors, free access to the production of goods at all levels, including property protection, permitting and resolving conflicts»» [7].

Unlike all other social systems, where there is a monopoly right to violence and coercion, the natural order involves an armed civilian population that is able to defend the property and its rights. H.-H. Hoppe emphasizes that the micro level within private property is characterized by «high discrimination, segregation, spatial separation, uniculturalism (cultural homogeneity), exclusive law and marginalism» [7], while the macro level cannot be called «equal», but, on the contrary, «Elitist», and «hierarchical», «proprietary», «patriarchal» and «authoritarian». The stability of a similar social system is based on the existence of an aristocracy that recognizes itself and is voluntarily universally recognized. It formed spontaneously within the framework of the process of socio-evolutionary selection. At the same time, these elites act as guarantors of the functioning of non-state institutions (private farms, church, contractual obligations, community and community).

Thus, the natural is the order in which homework and the libertarian ethical principles of belonging themselves are absent at the stage of realization. In essence, postulates the following statement: «The more monopoly coercion, the further the social system is from the natural order». The problem of the relationship between government and the market is considered H.-H. Hoppe through the prism of the above concept, where power (in the sense of «Macht») is conceived in the context of «coercion» and «physical violence». Under duress, the Austrian understands the powerful way of pushing someone to do something, while it is very important to distinguish between private coercion in a society of natural order and monopoly compulsion with taxation in all other social systems.

In the case of private coercion, a private conflict situation arises, which, according to the position of the scientist, is solved in the light of the existence of an extensive insurance system, which suggests that a separate coercive case is not capable of disturbing the public balance based on respect and realization of the rights of self-affiliation and homestead. Another thing is the existence of a monopolist, who makes coercion on the expropriated territory. In essence, it is a state that, 
using the power of taxation, insists that the final decision in any conflicts that arise between residents of a particular territory has always remained for it (final approval) [7]. This case is devastating for society, since it maximizes «power over people» and sets the tendency to minimize «domination over nature».

In his work «Marxist and Austrian Class Analysis» (1990) H.-H. Hoppe, considering the problem of institutional coercion, analyzes the theses of the Marxist theory of history (the entire history of mankind is the history of class struggle, the ruling class is uniting its interest: maintaining the position of the exploiter and maximizing expropriated excess; class domination manifested in industrial relations; competition between groups of the ruling class leads to greater concentration and centralization of power; with the growth of centralization and concentration of power, contradictions between classes reach their climax and in a certain moments will become incompatible with the further development of «productive forces»). In general, he agrees with these theses, he criticizes the Marxist theory of exploitation, while noting the equity of the author's «Capital» judgments about the existence of operational relations in pre-capitalist societies. H.-H. Hoppe emphasizes the difference in the nature of industrial relations within the slave and feudal system and in capitalism. If you use the «Austrian theory of exploitation», then there will be a striking difference between the relations of the slave and the slave, the feudal lord and serfs, the capitalist and the hired worker. The line of fault lies in «recognition or non-recognition of the homestead principle» [8, p. 83]. The Austrian states that the author of «Capital» mistakenly considers the capitalist mode of production exploitative, since «does not understand the phenomenon of temporary superiority as a universal category of human activity» [8, p. 82]. Exploitation - «It is an expropriation of developers, producers and custodians. It is observed when the principles of belonging and homestead are violated, as in the case of slavery and feudalism, but capitalism is a unique economic system that is both moral and mutually beneficial for owners of means of production and employees».

Reflecting on the historical phenomenon of institutional coercion, the scientist believes that people who prefer exploitation, united into groups, creating «large-scale exploiting enterprises, governments and states» [8, p. 84]. Unlike private enterprises operating in harsh market conditions, the ruling class at the head of the state, in essence, appears to be an institutionalized exploiting enterprise whose force depends on the segregation of the population whose private property rights are suppressed by this class. The tendency towards business concentration is the signal of the «nationalization» of economic life [8, p. 88]. The deeper the state penetrates the life of society, the more it contributes to the concentration of business in the hands of pro-government businessmen, and the more social system departs from the natural order. In essence, the interests of the state, based on the practice of exploitation, and the interests of the market, are based on the practice of development, production, sale and contract, the opposite, more precisely - antagonistic.

An important aspect of institutional coercion is its main instrument - taxation. H.-H. Hoppe article «The Economics and Sociology of Taxation» (1990) is devoted, first, to explaining the general economic implications of taxation, and, secondly, answers to the question: "Why is there taxation? And why is it becoming more and more?» [9, p. 33]. From the standpoint of praxeology, the tax always has a negative impact on production, contributing to the reduction of social wealth, since taxation itself is «it is forced, not a contractual transfer of certain physical assets (in our day it is usually money, but not only) and invested they have the value of those individuals or groups that owned these assets and could receive income from ownership in the future into the hands of other people or groups that now become owners and can earn income» [9, p. 34].

To clearly demonstrate the devastating impact of taxation on society, H.-H Hoppe gives an example of the taxation of monetary assets, which contributes to the depreciation of money, which in turn leads to two important consequences: firstly, the marginal utility of leisure increases, and, secondly, increases the marginal usefulness of future assets that we usually buy for money. Since they seek to avoid the depreciation of money and convert them into assets with a pronounced consumer value, the way of acquiring these goods looks much more attractive, which means, on the 
one hand, the chain of production steps is shrinking (reduction of investments in production-driven distant consumption sectors and the transfer of capital to the consumer sector), on the other hand, the direct exchange, i.e. barter, is becoming more and more attractive.

Concerning the answers to the above-mentioned questions, they can be formulated briefly in the following form. Firstly, the essential points here are, firstly, the lack of demand for taxation, and secondly, the consolidation of the practice of collecting taxes by coercion and, finally, the scale of the impact of ideology on the society, which is more effective than the more legitimate actions of the government in the focus of public opinion. On the other hand, the decisive role of public opinion within the framework of the problem of accepting the expansion of government functions or protesting against it, where four important factors contributing to the slow, but radical changes that were adversely affected by the idea of justice in the public consciousness [15, p. 50], after the transformation from the ethics of private property and the natural rights of classical liberalism to the egalitarian ethics of socialism. H.-H. Hoppe distinguishes the following factors of this metamorphosis: the transformation of the state from the police to redistributive and regulatory; constitutional changes (transition from monarchy to liberal democracy); inter-state rivalry (the tendency to increase nationalism and militarization); external framework («the existence of different states imposes significant restrictions on the size and structure of each of them») [9, p. 71].

All of the above-mentioned factors directly influence the growth of taxation, concentrating public opinion on the wave of statistics. The Austrian is convinced that it is in vain to struggle with the exploiting enterprise by the method of boycotting or aggressive resistance, since in general social discourse is a state position. The only way to address the ethics of private property and change public opinion. According to H.-H. Hoppe, «this idea must be reborn and once again inspire the minds and hearts. The idea of private property has one undeniable advantage: it alone is the true expression of human nature as a rational being» [9, p. 74-75]. In his work «A Theory of Socialism and Capitalism» (1989), the scientist defines socialism as «institutionalized intervention, or aggression, against private property and private property rights» $[10, \mathrm{p} .2]$, thereby demonstrating his commitment to the metaphysics of «natural order».

Conclusions. Firstly, all economic benefits convinced H.-H. Hoppe, a person acquires two ways: either through the development, production and acquisition on the basis of a contract, or by the method of expropriation of the benefits of those who prefer the first method. The subject, having found between choosing these methods, actually chooses between the format of performance or exploitation. If the first method corresponds to the ethics of private property that the Austrian justifies, based on the principles of the theory of communicative action by J. Habermas, and stimulates the growth of «domination over nature», creating a market, then the second, on the contrary, operates the concepts of the ethics of egalitarianism, raising the significance of «power over people», and thus reduces the level of public welfare, destroying market relations.

Secondly, productive and exploiting firms are antagonists. This is because the latter always seek to capture the wealth of the first. At the same time, H.-H. Hoppe, the exploiters cannot do without the developers and producers, and therefore they are looking for a way of legitimate coercion, which can be considered the emergence of the state - a system of institutional coercion, supported by public opinion. Its main instrument, aimed at expropriating funds from productive enterprises, is taxation, which, however, is in its pure form better than all regulatory measures applied to manage the economy of the controlled territory. If taxation and regulation increase, then the state is increasingly approaching a «socialist state» that systematically violates the ethics of private property.

Thirdly, what can be done in this situation for productive firms that suffer from the coercion of the exploiters? They, in the opinion of the Austrian researcher, can and must realize their commonality and consolidation by popularizing the ideas of private property ethics in order to influence public opinion, which, in turn, will contribute to the establishment of a natural order based on the absolutization of the principles of this ethical direction. In this point H.-H. Hoppe turns to praxeology, the principles of belonging to the homosexuality, and formulating the theory of the economy of power. For him, power is a coercion that becomes horribly devastating, turning into a 
state institution. It kills the creative potential of a person by reducing or completely destroying the level of «domination over nature». It threatens the normal work of the market, while having the «right» of legitimate violence, receives a clear advantage.

Fourthly, among the tangible disadvantages of the Austrian scholar's approach, there are several. First of all, the moral conditionality of his theory, dissonant with its scientific substantiation (given the fundamental impossibility of verifying it), because H.-H. Hoppe, by creating his own conception, tries to propagate the values and ideals of libertarianism, thereby marginalizing the Mises-Rothbard direction of the new Austrian school. Relying on the universal way of thinking, the a priori and the praxeological paradigm, he proposes a picture of the «natural order» isolated from reality and the human model, ignoring the tendency of the majority to minimize the risk and uncertainty, as well as the passivity inherent in the masses. A radical departure from empiricism gives rise to a beautiful mosaic and extra metaphysics (the laws of a priori thinking are projected onto the laws of social reality), which leads to the utopian world of «natural order» as an area of absolute freedom without borders and prohibitions, in which there is no place for the state. All relations are based on morality, and any deviations are offset by the insurance agencies system. But the questions of the following nature remain open: what exactly will the insurance agencies keep from transforming into states? What guarantees are the market-dominant insurance company will maintain parity with others, rather than decide to use the leading position to become an expropriator? And other firms cannot go this way? What are the criteria for the differentiation of a compulsory and voluntarily concluded contract between a simple member of a society and insurance agencies possessing means for forceful coercion to the contract? And in the end, what mechanisms to prevent the emergence of the state? These and other issues emphasize universalism as the ethics of private property as well as the position of the scientist himself, which leads to the creation of a purely speculative concept of «natural order», implemented in the framework of anarcho-capitalism.

\section{References (in language original):}

1. Boettke, J., Leeson, T. 28A: The Austrian School of Economics: 1950-2000 / J. Boettke, T. Leeson // Sanuels, Warren J.; Biddle, Jeff E.; Davis, John B. A companion to the History of Economic Thought. - Blackwell Publishing, 2003. - P. 445-454.

2. Mises L. von. Epistemological Problems of Economics / L. von. Mises. - New York and London: New York University Press, 1981. - 259 p.

3. Хайек Ф. А. фон. Судьбы либерализма в ХХ веке / Ф. А. фон. Хайек. - М., Челябинск: ИРИСЭН, Мысль, Социум, 2009. - 337 с.

4. Machlup F. Ludwig von Mises: A Scholar Who Would Not Compromise [Electronic recourse] / H.-H. Hoppe // MISES DAILY. 2004. - Accessed mode: https://mises.org/library/ludwig-von-misesscholar-who-would-notcompromise

5. Hoppe H.-H. Murray N. Rothbard: Economics, Science, and Liberty / H.-H. Hoppe // The Ludwig von Mises Institute. Reprinted from 15 Great Austrian Economists, ed. by R. G. Holcombe, 1999. - P. 223-241.

6. Hoppe H.-H. Democracy - the god that failed: the economics and politics of monarchy, democracy and natural order / H.-H. Hoppe. - New Brunswick, New Jersey: Transaction Publishers, 2007. - 304 p.

7. Hoppe H.-H. Democracy is an overthrown god. Comment [Electronic recourse] / H.-H. Hoppe // Internet media "LibertyNews". 2001. - Accessed mode: http://libertynews.ru/node/978

8. Hoppe H.-H. Marxist and Austrian Class Analysis / H.-H. Hoppe // The Journal of Libertarian Studies. - 1990. - Vol. IX, №2. - P. 79-93.

9. Hoppe H.-H. The Economics and Ethics of Private Property / H.-H. Hoppe. - Auburn, Alabama: Ludwig Von Mises Institute, 2006. - 433 p.

10. Hoppe H.-H. A theory of socialism and capitalism: economics, politics, and ethics / H.-H. Hoppe. - Auburn, Alabama: Ludwig von Mises Institute, 2010. -265 p.

11. Заостровцев А. П. Современная австрийская школа об институтах, проблемах развития и роли экономиста / А. П. Заостровцев // Вопросы экономики. - 2015. - № 7. - С. 73-86.

12. Ковалев А. В. Австрийская школа: от методологии к объяснению кризисов / А. В. Ковалев. - М.: Институт экономики РАН, 2015. - 49 с.

13. Ковалев А. В. Теория экономического цикла австрийской школы: эволюция и современное состояние / А. В. Ковалев // Экономическая политика. - 2015. - Т. 10. - № 2. - С. 43-62. 
14. Усанов П. В. Экономическая феноменология как метод политической экономии австрийской школы / П. В. Усанов // Terra Economicus. - 2010. - Т. 8. - № 4. - С. 47-56.

15. Уэрта де Сото Х. Австрийская школа: рыночный процесс и предпринимательское творчество / Х. Уэрта де Сото. - Челябинск: Социум, 2009. - 202 с.

16. Hoppe H.-H. Economic Science and the Austrian Method / H.-H. Hoppe. - Auburn, Alabama: Ludwig Von Mises Institute, 2007. -88 p.

17. Schulak E. M. The Austrian School of Economics: A History of Its Ideas, Ambassadors, and Institutions / E. M. Schulak, H. Unterköfler. - Auburn, Alabama, 2011. - 244 p.

\section{References:}

1. Boettke, Peter J., Leeson, \& Peter, T. (2003). 28A: The Austrian School of Economics: 1950-2000. In Sanuels, Warren J.; Biddle, Jeff E.; Davis, John B. A companion to the History of Economic Thought, 445-454. Blackwell Publishing

2. Mises, L. von (1981). Epistemological Problems of Economics. New York and London: New York University Press.

3. Hayek, F. A. von (2009). The fate of liberalism in the XX century. Moscow, Chelyabinsk: Mysl', Sotsium (in Russ.)

4. Machlup, F. (2004). Ludwig von Mises: A Scholar Who Would Not Compromise. MISES DAILY. Retrieved from: https://mises.org/library/ludwig-von-misesscholar-who-would-not-compromise

5. Hoppe, H.-H. (1999). Murray N. Rothbard: Economics, Science, and Liberty. The Ludwig von Mises Institute. Reprinted from 15 Great Austrian Economists. R. G. Holcombe (Ed.), 223-241.

6. Hoppe, H.-H. (2007). Democracy - the god that failed: the economics \& politics of monarchy, democracy \& natural order. New Brunswick, New Jersey: Transaction Publishers.

7. Hoppe, H.-H. (2001). Democracy is an overthrown god. Comment. Internet media "LibertyNews". Retrieved from: http://libertynews.ru/node/978

8. Hoppe, H.-H. (1990). Marxist and Austrian Class Analysis. The Journal of Libertarian Studies, IX, 2, 79-93.

9. Hoppe, H.-H. (2006). The Economics and Ethics of Private Property. Auburn, Alabama: Ludwig Von Mises Institute.

10. Hoppe, H.-H. (2010). A theory of socialism and capitalism: economics, politics, and ethics. Auburn, Alabama: Ludwig von Mises Institute.

11. Zaostrovtsev, A. P. (2015). Modern Austrian school about institutions, problems of development and the role of economist. Voprosy ekonomiki (Economic issues), 7, 73-86 (in Russ.)

12. Kovalev, A. V. (2015). Austrian school: from methodology to explaining crises. Moscow: Institute of Economics (in Russ.)

13. Kovalev, A. V. (2015). The theory of the economic cycle of the Austrian school: evolution and current state. Ekonomicheskaia politika (Economic policy), 10, 2, 43-62. (in Russ.)

14. Usanov, P. V. (2010). Economic phenomenology as a method of political economy of the Austrian school. Terra Economicus, 8, 4, 47-56 (in Russ.)

15. Huerta de Soto, J. (2009). Austrian School: Market Process and Entrepreneurial Creativity. Chelyabinsk: Social life (in Russ.)

16. Hoppe, H.-H. (2007). Economic Science and the Austrian Method. Auburn, Alabama: Ludwig Von Mises Institute.

17. Schulak, E.M. \& Unterköfler, H. (2011). The Austrian School of Economics: A History of Its Ideas, Ambassadors, and Institutions. Auburn, Alabama.

\section{ПЕЧЕРАНСЬКИЙ Ігор Петрович,}

доктор філософських наук, доцент,

професор кафедри філософії

Київського національного університету

культури і мистецтв,

e-mail: ipecheranskiy@ukr.net

\section{ПРИНЦИП НЕВТРУЧАННЯ ВЛАДИ ТА ЙОГО ЕТИЧНЕ ОБГРУНТУВАННЯ У РОБОТАХ ГАНСА-ГЕРМАНА ГОППЕ}

Проблема. Одним з найвідоміших представників напряму, започаткованого Л. фон Мізесом та М. Родбардом, є прибічник австрійської школи в економічній науці Ганс-Герман Гоппе. Дослідження його поглядів представляє суттєвий інтерес в контексті розуміння вихідних принципів та особливостей сучасного анархо-капіталізму та лібертаріанства.

Метою статті є розкриття змістовних аспектів та методологічного значення принципу невтручання влади й здійснення аналізу його етичного обтрунтування у праиях відомого 
представника «нової австрійської иколи» Ганса-Германа Гоппе.

Методи. Методологічною основою дослідження є використання як загальнонаукових, так $i$ соціологічних методів. Теоретичним та методичним підгрунтям роботи $\epsilon$ система загальнонаукових ци спецііальних методів: історико-логічного, теоретичного узагальнення та систематизаиіï.

Результати. Доведено, щуо вчений, опираючись на апріоризм, праксеологію та принципи самоприналежності й гомстеда, створює власну теорію економіки влади, де основним об'єктом критики є держава як інституціолізована форма примусу й експлуатації.

Наукова новизна. Обгрунтовано, щзо Ганс-Герман Гоппе відстоює універсалізм етики приватної власності, який трансформується у створення умоглядної концепції «природного порядку», реалізованої в рамках анархо-капіталізму мізесіансько-ротбардіанського напрямку «нової австрійської иколи».

Висновки. Для Ганса-Германа Гоппе влада - це примус, щуо набуває страхітливо-руйнівних маситабів, перетворюючись на державну інституцію. Вона вбиває креативний потенціал людини, знижуючи або ж зовсім руйнує досягнутий рівень «панування над природою», а також загрожує нормальній роботі ринку, при цүьому, володіючи «правом» легітимного насильства, отримує явну перевагу. Саме тому вчений зосереджує велику увагу на етичному обтрунтуванні принципу невтручання влади у економічні прочеси.

Ключові слова: «нова австрійська школа», Ганс-Герман Гоппе, апріоризм, праксеологія, універсалізм, етика приватної власності, невтручання влади.

Одержано редакиією 01.11.2019

Прийнято до публікаичї 04.12.2019

УДК: 101.1; 371.13

DOI: 10.31651/2076-5894-2019-2-23-30

\author{
ГАНАБА Світлана Олександрівна, \\ доктор філософських наук, \\ професор кафедри педагогіки \\ та соціально-економічних дисциплін \\ Національної академії Державної \\ прикордонної служби України \\ імені Богдана Хмельницького, \\ e-mail: sveta_ganaba@ukr.net
}

\section{ВПЛИВ МЕРЕЖЕВИХ ТЕХНОЛОГІЙ НА КОМУНІКАЦІЮ ЛЮДИНИ: СОЦАЛЬНО-ФІЛОСОФСЬКИЙ АСПЕКТ}

Сучасні науково-технічні відкриття зумовили виникнення нових культурних форм, до яких належить світове павутиння (мережа). Визначальними у реаліях сучасного світу є прочеси й явища, які організовуються й функціонують за принципом мережі, ефективність якої полягає в тому, щзо вона дає змогу успішно регулювати складну систему взаємозалежних економічних та соціальних факторів. Уже сьогодні мережа досить органічно увійила у світ людини, проникла у всі соціокультурні практики аж до повсякдення, зачепивши ї фізіологічну та психологічну природу. Мова йде про низку антропологічних зрушень, дослідження й розуміння яких допоможе зрозуміти соиіокультурну природу сучасності. Метою статті є розгляд соичіального аспекту впливу мережевих технологій на комунікацію людини як важливу онтологічну сутність людини. Мережа розглядається не як інертна до користувача, вона виявляє здатність суттєво впливати на його інтелектуальну, емоційну, моральну, духовну, тілесну тощуо субстанціональність. У мережних технологіях спостерігасмо антропологічні зрушення, які трунтуються на смислових засадах соціокультурного та психологічного відчуження та маргінальності, які, як наслідок, супроводжується аксіологічними трансформаціями. В умовах ицього світу людина позбувається иентризму, чітко окреслених смислових меж та сукупності психічних, фізіологічних, пізнавальних й інших здібностей, узвичаєних образів. 